\title{
THE THEORETICAL CONCEPTS OF INNOVATIVE POTENTIAL FORMATION OF NATIONAL ECONOMY
}

Introduction. The transition to social development in the fourth technological way requires the search for fundamentally new concepts of forming the innovative potential of the national economy, as existing approaches and mechanisms require some transformation.

The potential of a separate system of lower (primary) level and the constituent elements of this potential directly affect the state and prospects of the national economy as a whole and, according to researchers [10; 13], it is the innovation potential that leads to the effective development of the system in the long run.

Thus, the scientific research of the main results which are presented in this article is timely and relevant.

The theoretical and methodological basis for the research of this topic was formed by the works of leading scientists who are the specialists in the issues under study, in particular, Ed.F. Aunapu [4], A. Badrak, L. Shostak [3], T. Konno [7], R. Nelson, S. Unther [11], G. Haken [14] and others; however, the fundamental importance of the studied problem, its versatility and multi-vector encourage further search and solution of these scientific challenges through the prism of the modern stage of society.

The purpose of this study is to identify and study the theoretical concepts of forming the innovation potential of the national economy.

The study was conducted in the framework of research on "The formation of theoretical and methodological foundations of economic development of the region and its assessment in the strategic perspective" (state registration number 0110U006871), "Theoretical and methodological justification and practical implementation of management of competitive advantages of regions account of the development of enterprises of the maritime complex" (state registration number 0116U003213).

Statement of basic materials. In the process of determining the essence of any kind of potential of the economic system, the fact is recorded that the former itself is a complex system of interacting elements that can, to some extent, replace each other (be alternative and dynamic).

The potential of its detection can independently adapt and evolve with the emergence of new components and provided a balanced optimal relationship between them. Considering the essence of the process of capacity building, given that it is itself a hierarchical system, it is necessary to define in more detail the properties and qualities inherent in the system in general.

In the authors' opinion, it is advisable to distinguish between qualitative characteristics of the system at the levels of essence (quality of the system) and manifestation (set of properties). The quality of the system means a significant certainty of the subject, due to which it is a given and not another subject.

The quality of an object is related to the object as a whole, encompassing it completely and determining its specific properties.

A property is an aspect of an object that emphasizes its difference or similarity to other objects and manifests itself in interaction with them. Each object has a number of properties, the unity of which characterizes its quality [13; 15].

Given the above-mentioned, the list of qualitative characteristics and properties can be structured by highlighting the qualities of the national system, the properties of the first and second order (see Table). 
Qualities and properties of the national system

\begin{tabular}{|c|c|c|}
\hline \multirow{2}{*}{ System quality } & \multicolumn{2}{|c|}{ System properties } \\
\hline & I order & II order \\
\hline \multirow{3}{*}{ Hypercomplexity } & Complexity & Multivalence \\
\hline & Multidimensionality & Alternative \\
\hline & Integrity & Stationarity \\
\hline \multirow{7}{*}{ Dynamism } & \multirow[t]{2}{*}{ Uncertainty of behaviour } & Adaptability \\
\hline & & Stability \\
\hline & \multirow[t]{5}{*}{ Nonlinearity } & Stochasticity \\
\hline & & Evolution \\
\hline & & Flexibility \\
\hline & & Limit \\
\hline & & Multivalence \\
\hline \multirow{3}{*}{ Emergence } & Structurality & \\
\hline & Hierarchy & \\
\hline & Antientropy & \\
\hline \multirow{2}{*}{ Synergism } & \multirow{2}{*}{$\begin{array}{l}\text { Purposefulness } \\
\text { (teleonomy) }\end{array}$} & Multiplicity \\
\hline & & Combinatoriali \\
\hline
\end{tabular}

Hypercomplexity is a qualitative characteristic of the system as a whole, which implies the presence of such system properties of the first order as complexity, multifaceted connections of elements, components, subsystems.

The components or elements of a system have a set of properties and connections, i.e. they are multivalent, which allows these elements to become an effective part of different types of systems.

If the properties of the system as a whole change, it will be reflected in the changing characteristics of its elements, the emergence of potential alternative states of the system and ways of development.

Dynamism as an important qualitative characteristic of the system is associated with changes in its quantitative and qualitative parameters as a whole. Depending on the depth and scale of changes in the elements, there are uncertainties and nonlinear behaviour of the system.

One of the main manifestations of behavioural uncertainty is fluctuations - small random disturbances, or bifurcations - breakthrough phenomena in economic processes.

In the zone of so-called flexible behaviour, when the adaptive capabilities of the system are not exhausted, fluctuations do not violate its integrity and decrease over time to a certain minimum value.

In the zone corresponding to the critical values of the system parameters, the fluctuations increase, leading to bifurcation changes. Uncertainty of behaviour is also manifested in changes in the state of system flexibility when it tries to adapt to the influence of the external environment.

Adaptation and evolution are most closely related to two opposite properties inherent in the hypercomplexity of the system: integrity (closeness of connections between elements and subsystems, the level of unity of the system) and the totality (weakening of connections of subsystems and elements due to change stationary states of the system at a certain stage of its development).
Nonlinearity is the ability of a system to have in its structure different stationary states that correspond to different laws of this system functioning. The realization of the adaptive capabilities of the system is stochastic due to the multivalence of connections and states of the elements.

The growth of environmental changes can lead to the transformation of adaptive changes in the system into evolutionary changes, which is associated with the emergence of new elements, properties and relationships, changes in the structure and behaviour of the system, that is, there is a limit to the preservation of the properties of the system at a certain level (borderline changes in the properties of the system or its elements).

Emergence as a complex qualitative characteristic of the system allows determining the structure of elements at all levels of the system hierarchy (with a certain system becomes a subsystem of another, more complex system).

Emergence is associated with the development of such system properties as structure (connections of elements at certain levels of system organization), hierarchy (connection of internal levels of the system) and antientropy (orientation of the system to maintain its integrity).

For any complex dynamic system, synergism is manifested both by obtaining an additional effect due to its integrity and through the use of the possibilities of integration of system elements. Combinatorial and multiplicative effects, in this case, are observed as a natural result of successful goal-setting levels and subsystems as the whole.

Scientists, referring to the list of qualitative characteristics of potentiality, define it only as the presence of alternative opportunities for system development, which can be realized under certain conditions [10].

In authors' opinion, the understanding of the potential of the system has to be based on a direct study of its most significant (system-forming) characteristics. It is the potentiality that combines the most important 
qualitative features of the system: the hypercomplexity of the system, the emergence of its elements; dynamism of states and connections; the appearance of synergistic effects from the interaction of elements, and determines a certain level of system potential.

In relation to complex economic systems, the concept of "potential" is associated primarily with such types of economic potential as production, environmental, financial and credit, management, foreign economic, innovation. The innovation potential comes to the fore, which is associated with the transition to an innovative path of the domestic economy development.

Analysis of the economic aspects of the concept of "innovation potential" reveals a wide range of approaches to its study. Consider some of them:

- innovation potential is one of the three components of the innovation and information space, which includes personal and business qualities of managers, professional and economic training, professional achievements (copyright certificates, inventions, etc.), logistics and financial support [10];

- innovation potential is the implemented innovations;

- innovation potential is a set of different types of resources, including material, financial, intellectual, informational and other resources necessary for $[2 ; 3 ; 16]$;

- innovation potential contains untapped, hidden opportunities of accumulated resources that can be used to achieve the goals of economic entities [12];

- innovation potential is a category of special content, which includes not only innovation resources and the mechanism of their use in the organizational and economic system, but also the activity of innovation processes [14];

- innovation potential as an opportunity to implement for the first time or reproduce effective innovations based on the use of own or borrowed resources $[1 ; 7$; 14];

- innovation potential as the potential of knowledge obtained in the process of realization of scientific and technical potential, i.e. innovative potential is the total capacity of scientific and technical knowledge and practical experience that provide a fuller use of economic potential resources [6];

- the innovative potential of the economic entity is considered as a set of its tools and capabilities in the implementation of its innovation strategy [11].

Analyzing the variety of selected approaches to the definition of innovation potential, it has to be noted that they can all be divided into three main groups:

1) resource approach, i.e. the definition of innovation potential as a set of resources or a combination thereof;

2) a structural approach to the definition of innovation potential, according to which its main elements such as personnel, information-methodological, logistical, scientific-technical, financial components, etc.;

3 ) process approach, according to which the innovation potential is associated with the achievement of the goals of innovation activities of entities engaged in the development, implementation and commercialization of innovations.

According to the presented approaches, there are three levels of defining the essence of innovation potential: characterization of potential as a set of available or necessary resources; consideration of its internal structure; identification of system interaction of components of innovation potential in the process of achieving the set goals by the economic system.

Thus, researchers in their works directly touch on such qualities of innovation potential as: hypercomplexity and (to some extent) emergence and dynamism. However, in the concept of "innovation potential" they reveal not the most essential features of the studied object, but the properties of the second order (multivalence, limit, stochasticity, etc.), which are derived from systemic qualitative characteristics (dynamism, hypercomplexity, synergism, emergence).

The authors believe, the content of the concept of "innovation potential" has to begin at the conceptual level through the definition of system-quality primary categories, subordinated and coordinated with each other.

The logical connection of qualitative characteristics of innovation potential can be revealed by using an integrated approach to defining the essence of innovation potential and characterize the dialectic of formation and development of the latter.

The integrated approach, borrowing the advantages of all other approaches, allows analyzing the resource "filling" of innovation potential not as a simple set of elements, but as a dynamic hypercomplex system in which the structuring of elements occurs at certain levels of their hierarchical relationship.

The schematic diagram of the structure of resource elements of innovation potential at the first level of their hierarchical relationships is shown in Fig. 1.

The scheme presented in Fig. 1 illustrates the fact that the approach to considering the innovation potential of the national economy, only as a set of resources and opportunities for their use, is limited, because such an idea does not take into account the target characteristics of this category.

The use of resources within the innovation potential ought to be purposeful and in some way organized in order to form, coordinate and implement the innovative needs of enterprises, regions, society as a whole.

Thus, the structured purposefulness of resource elements is the key to the emergence of synergy as the most important system-qualitative characteristic of innovation potential.

The integrated approach allows supplementing the idea of the interconnection of resource components of innovation potential: it is possible to integrate resource elements of innovation potential into certain complexes, which allows more efficient maneuvering of finances, funds, personnel, information, etc. 


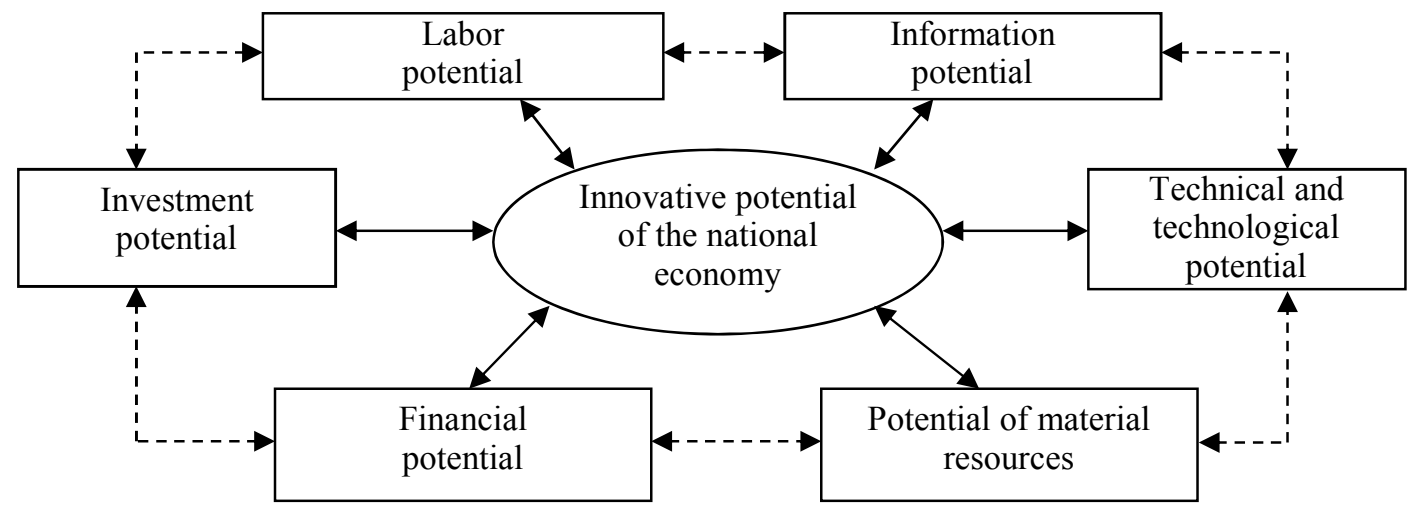

Fig. 1. Relationships of resource elements of innovation potential of the national economy the first level of the hierarchy

As a result, the structural components of the innovation potential of the national economy of the second level of the hierarchy are formed (Fig. 2).

According to Fig. 2, the scheme of relationships of resource elements of the innovation potential of the na- tional economy is complicated: there are integrated resource complexes of the second level, which combine resources, similar in the mechanism of action (investment and financial resources), by origin (intellectual resources, material assets).

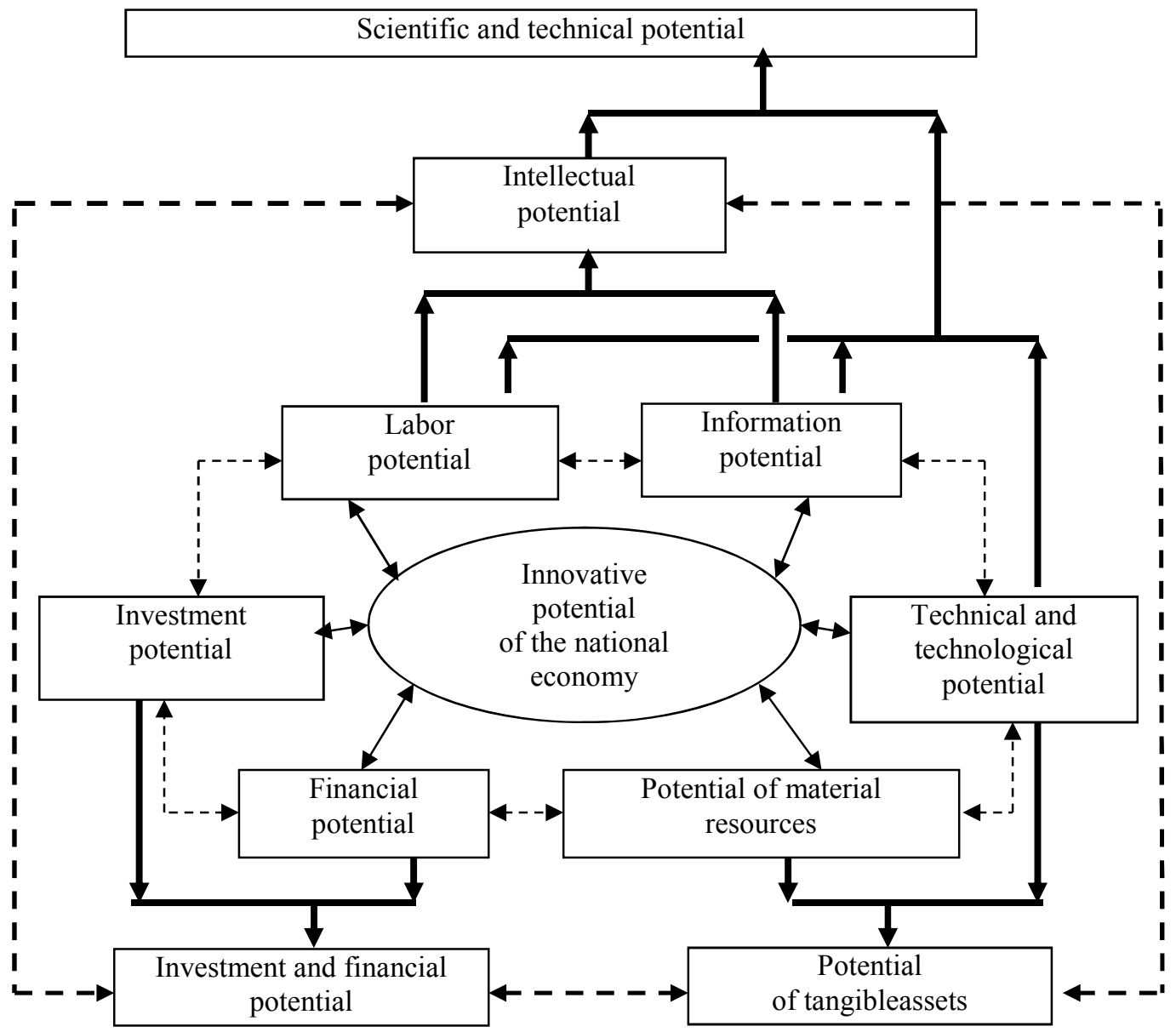

Fig. 2. Relationships of resource elements of innovation potential of the national economy the second level of the hierarchy

According to the end result of the use of resources, the scientific and technical potential is allocated, which is mostly associated with the innovative potential and which creates conditions for the transition of the latter to a qualitatively new level of development [4].
The authors state that the transition to an integrated approach allows eliminating the shortcomings of previous structural and process approaches. The structural approach does not show the process of its further development of innovation potential and its components 
under the influence of various factors. The process approach is underdeveloped because it generally provides for the exclusion from the concept of "innovation potential" of the scientific and technical component, and focuses only on the introduction and commercialization of innovations.

The study of the second level of the components hierarchy, on the principles of an integrated approach, is impossible without taking into account the dynamism of the processes of functioning of innovation potential, combining the stages of its formation, adaptation and development.

Characterizing certain stages of the functioning of innovation potential at any level of the national economic system, the idea of flexible development of micro-economic entities can be applied which is described in the works of V. Samochkin and T. Bozhidarnik, according to which the flexibility of microeconomic systems is associated with their ability to plan the process of their functioning in order to create conditions for effective reproduction of all economic processes and the ability to predict the process of its development, identifying potential and real opportunities for renewal under the influence of the environment $[5 ; 8]$.
The idea of flexible development of the innovative potential of microeconomic systems, which emphasizes their dynamism, is productive, primarily because it allows separating the stages of formation and development of capacity; identifying the conditions of the transition to each stage and the problems associated with these transitions; predicting the prospects for the development of innovation potential of micro-, macro- and mesoeconomic systems.

It has also to be noted that the model of flexible capacity development, corresponding to the philosophical concept of dialectics (development) of multilevel complex economic systems and marketing and logistics concept of the life cycle, gives the ground for direct exploration of the internal structure dynamism of innovation potential.

According to this model, the formation of innovation potential can be represented as a continuous change in the cycles of its operation, when the internal set of resources $(\mathrm{R})$ is formed, the ability (technical-technological, organizational) use of available resources (A) and opportunities to improve resource use models (U) established (Fig. 3).

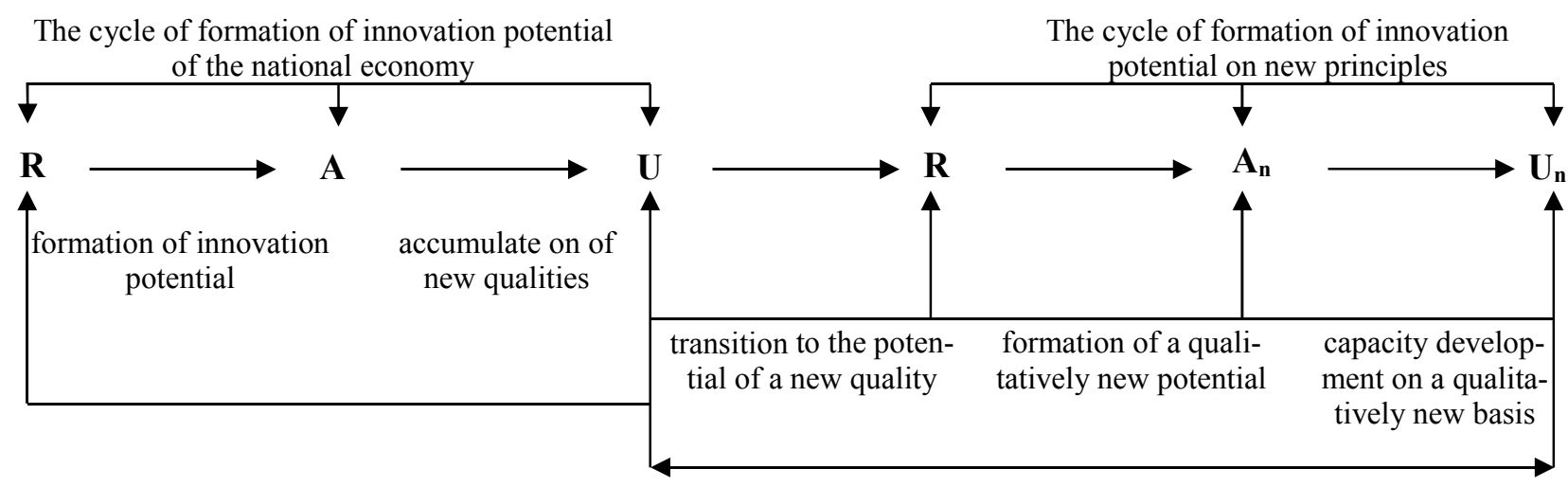
Maintaining the innovative potential of the economy within the old quality (simple reproduction of potential)

\section{Fig. 3. Cycles of formation and development of innovative potential of the national economy}

Analyzing the relationship between the states of innovation potential at different stages of its functioning within the national economy (Fig. 3), it has to be noted that the formation cycle highlights the process of organization, when based on a special selection of resources creates a mechanism of economic stability.

The accumulation of positive changes in economic processes, associated with the improvement of models, technological schemes for the use of available resources, allows creating a basis for the transition of innovation potential to a qualitatively new level (state).

The positive changes of an innovative nature that occur in the cycle of capacity building include such capabilities of the economy as:

- timely detection of innovative problems that arise in the set of consumers;
The cycle of development of the innovative potential of the economy (expanded reproduction)
- development and implementation of new products and technologies;

- assessment of the level of innovation of national investment projects;

- identification of innovative trends in national and global markets;

- participation in the creation of a single global innovation and information space.

The accumulation of positive changes in innovation potential can create conditions for the transition to the cycle of its flexible development, when capacity building takes place at a qualitatively new level, accelerates the development and implementation of new approaches, methods and schemes for optimizing the structure of resource-functional potentials.

Defining the features of cycles of formation and development of innovation potential, it ought to be men- 
tioned that there is a dialectical relationship between the stability of potential, when it is reproduced within the old quality, and flexible development, when potential is reproduced at a qualitatively new level (Fig. 4).

\begin{tabular}{|c|c|c|c|}
\hline \multicolumn{2}{|c|}{$\begin{array}{c}\text { Formation of innovation } \\
\text { potential }\end{array}$} & \multicolumn{2}{c|}{$\begin{array}{c}\text { Development of innova- } \\
\text { tion potential }\end{array}$} \\
\hline $\begin{array}{c}\text { Sustainabi- } \\
\text { lity potential }\end{array}$ & $\begin{array}{c}\text { Adaptation } \\
\text { potential }\end{array}$ & $\begin{array}{c}\text { Upgrade } \\
\text { potential }\end{array}$ & $\begin{array}{c}\text { Flexibility } \\
\text { potential }\end{array}$ \\
\hline & \multicolumn{2}{|c|}{ Potential of formation } & \\
\cline { 2 - 4 } & \multicolumn{3}{|c|}{ Development potential } \\
\hline \multicolumn{3}{|c|}{ Functioning potential } \\
\hline
\end{tabular}

Fig. 4. Matrix of states of innovation potential of the national economic system

Analyzing the matrix of potentials of the national economic system, it ought to be mentioned that the potential of sustainability can be represented as a dynamic balance between the ability and capacity of the system to maintain the integrity of the old quality of its resources, processes (reproduce them at the same level) and the ability to adapt to internal and the external environment, without rejecting the positive changes of innovative nature and thus improving the state of its innovative potential.

The comparison of cycles of formation and development of national innovation potential allows deepening the characteristic of its structural elements.

The state of innovation potential at different stages of its operation differentiates the significance of its certain components.

Thus, considering the innovation potential in statics, it can be noted that at the stage of formation of special importance are the components of the first level, such as the financial component, management of which should provide the optimal resource structure for creating and implementing innovations.

At the stage of adaptation, the components of the second level are of increased importance: intellectual, investment-financial and material. The components of the second level form additional opportunities for adaptation of innovation potential to the influence of internal and external factors, contribute to the implementation of the idea of economic development on an innovative basis.

At the stage of renewal, the components of the third level become extremely important - the scientific and technical component that is considered the impetus and criterion for further development of innovation potential, and the cultural and educational component. These components in their relationship form the innovative culture of society and the external and internal environment conducive to the innovation of economic entities.

The upgrade stage will provide a transition to the stage of flexibility potential, which indicates that the innovation potential of the system has reached a qualitatively new level of development.

The features of a new quality of innovation potential can be considered: increasing the competitiveness of innovative products in national and global markets; reduction of innovation lag (time between development and implementation of innovations); increasing the level of specialization and cooperation of innovation entities; efficient operation of innovation infrastructure; increasing the number of knowledge-intensive innovative products, etc.

The downturn tendency in industrial production has led to Ukraine's heavy dependence on foreign trade. If in the US and Japan exports of goods account for only $8 \%$ of GDP, and in France and Poland about 22\%, in Ukraine in 2010 the figure was almost 65\%, mainly due to raw materials and semi-finished products [13].

It follows from the above-mentioned that given the classical structure of the economic cycle and guided by indicators that characterize the real state of the industrial economy nowadays, it can be stated that Ukrainian industry has passed the phase of depression and is in recovery.

On the basis of the conducted research, it is necessary to allocate directions of the industrial enterprise development which will provide effective use and directions of reproduction of their potential of social and economic systems:

- modernization and technical re-equipment of the main part of production facilities;

- increasing the technological level of production, expanding the level of exports through the production of high-tech products;

- increasing the level of labour potential by eliminating the unproductive use of labour resources, maintenance of surplus labour resources, hidden unemployment in various forms;

- reduction of material consumption of products and introduction of resource-saving, waste-free and low-waste technologies in order to increase the level of production of competitive products.

Conclusions. Thus, the peculiarities of the national level systems development in modern conditions revealed in the research process are a prerequisite for thorough study, improvement of existing and development of scientific and practical recommendations for building an effective management system for the formation and effective development of the national economy.

The necessity of managing the potential of the national economy, which is conditioned by the modelling of the potential development, is determined and substantiated; defining the best ways to use it.

It is proved that in relation to complex economic systems, in particular at the national level, the concept of "potential" is associated primarily with such types of economic potential as production, environmental, financial and credit, management, foreign economic, innovation, with innovation potential coming to the fore, which is associated with the transition to an outstanding path of the domestic economy development.

While analyzing the variety of approaches to the definition of innovation potential it has been established that they can all be divided into three main groups: re- 
source approach, structural approach, process approach, which determine respectively three levels of determining the essence of innovation potential: characterization of potential as a set of available or required resources; consideration of its internal structure; identification of systemic interaction of the components of innovation potential in the process of achieving the socio-economic system goals.

Analysis of the relationship between the states of innovation potential at different stages of its operation, namely the stages of formation, adaptation and development, it has been defined that the formation cycle can be explicit as the process of formation when based on a special selection of resources mechanisms for the stability of socio-economic systems.

Analysis of the matrix of states of innovation potential of the national economy showed that the potential of sustainability can be represented as a dynamic balance between the ability and capacity of the system to maintain the integrity of the old quality of its resources, processes and ability to adapt to the internal and external environment, thereby improving the state of its innovation potential.

The upgraded stage will provide a transition to the stage of flexibility potential, which indicates that the innovation potential of the system has reached a qualitatively new level of development, which is characterized by increasing the competitiveness of innovative products; reduction of innovation lag; effective operation of innovation infrastructure.

Further research has to be focused on the development of economic and mathematical tools to assess the status and prospects of long-term sustainable development of individual components of the innovation potential of the national economy in order to build a multivariate model of effective management of both innovation potential and the national economy as a whole.

\section{References}

1. Ansoff, I. (1999). New corporate strategy. Transl. from Engl. St. Petersburg, Peter Com. 416 p. [in Russian].

2. Afanasyev, V. (1964). The issue of integrity in philosophy and biology. Moscow. 101 p. [in Russian].

3. Badrak, A., Shostak, L. (2002). Goals and priorities of sustainable development of Ukraine. Economy of Ukraine, No. 10, pp. 30-36 [in Ukrainian].

4. Aunapu, F. (Ed.). (1972). Diagnostics of production systems. Irkutsk, ICSTI. 39 p. [in Russian].

5. Rapoport, V. (1988). Management diagnostics: practical experience and implementation. Moscow, Economics. 127 p. [in Russian].

6. Zabrodsky, V., Kizim, N., Yanov, L. (1997). Modern methods of organization and management of industrial production. Kharkiv, Business Inform. 64 p. [in Russian].

7. Konno, T. (1998). Strategy and structure of Japanese enterprises. Transl. from Engl. Moscow, Audit, UNITY. 279 p. [in Russian].

8. Korotkov, E. (1997). Management Concept. Moscow, Deka. 304 p. [in Russian].
9. Litvak, B. (2000). Development of management decisions. Moscow, Delo. 392 p. [in Russian].

10. Solokha, D., Bandura, M., Savchenko, M., Moreva, V. (2011). Methodological foundations of managing steel and innovative development of the potential of social and economic systems in a region: monograph. Donetsk, "Knowlej". 431 p.

11. Nelson, R., Unther, S. (2000). Evolutionary theory of economic change. Moscow, Finstatinform. 474 p. [in Russian].

12. Prigogine, I., Stengers, I. (1986). Order out of chaos: a new dialogue between man and nature. Transl. from Engl. Moscow, Progress. 432 p. [in Russian].

13. Solokha, D. (2012). Use of the Theory of Growth in Working Out of Conceptual Components of Strategy of Development of Innovative Potential of Region. The $A d-$ vanced Science Journal. The United States, pp. 34-38.

14. Haken, G. (1980). Synergetics. Transl. from Engl. Moscow, Myr. 328 p. [in Russian].

15. Shumikhin, V., Zakharchenko, E. (2005). Technopolises - the engine of innovative development of regions. Intellectual property, 7, pp. 32-37 [in Ukrainian].

16. United Nations. A review of Public-Private Partnerships for Infrastructure Development in Europe (1113 March, 2002). Economic Commission for Europe, Working Party on International Legal and Commercial Practice. Retrieved from https://ppiaf.org/sites/ppiaf.org/ files/documents/toolkits/Cross-Border-Infrastructure-Toolk it/Cross-Border\%20Compilation $\% 20$ ver $\% 2029 \% 20 \mathrm{Jan} \%$ 2007/Resources/UNECE\%20-\%20Review\%20of\%20PPP $\% 20$ for $\% 20$ Infrastructure $\% 20$ Devt $\% 20$ in $\% 20$ Europe.pdf.

Кендюхов О. В., Солоха Д. В., Танчик О. І., Бєлякова О. В. Теоретичні концепції формування інноваційного потенціалу національної економіки

Розглянуто основні підходи до оптимізації конкурентних переваг господарюючих суб'єктів України в контексті реалізації основних положень концепції сталого розвитку з урахуванням критерію екологічної ефективності.

Виробникам екологічних інновацій при оцінці своїх шансів на ринковий успіх слід враховувати вплив факторів екологічного тиску і негативного впливу навколишнього середовища. Існують радикальні екологічні інновації, які не мають прямих аналогів. Для даного виду інновацій при аналізі попиту та оцінці ринкових перспектив рекомендується враховувати наступні фактори: критичний рівень споживчого капіталу, критичну придатність продукту, критичний мінімальний рівень доходу, критичний рівень ризику і критичний обсяг вільного часу споживача. Швидкість подолання цих бар'єрів впливає на час, необхідний для впровадження екологічних інновацій на ринок, початок генерування попиту і збільшення продажів.

Для формування внутрішнього ринку екологічно чистої продукції необхідно створити адаптовану нормативну базу для стимулювання виробників і створення конкурентного середовища. Представлено механізм розробки стратегії розвитку господарюючих суб'єктів 3 виробництва екологічно чистих товарів. Стратегія представлена як узагальнююча модель дій, необхідних для досягнення мети. Стратегічні впливи доцільно здійснювати за певним алгоритмом, що представляє собою логічну послідовність. 
Запропоновано процедуру сертифікації екологічно чистих товарів та алгоритм даного процесу на основі критерію екологічної ефективності виробничих систем. Сертифікація дозволяє отримати повну і достовірну інформацію про виробництво екологічно чистого товару на всіх етапах, дає споживачам гарантію дотримання норм і стандартів, що підтверджують екологічну чистоту продукції.

Об’єктивне комплексне виявлення потреб основних груп споживачів поступово формує основу функціонування ринку екологічно чистих товарів. Діагностичний підхід до його формування повинен використовуватися в поєднанні з оптимізаційним підходом, який реалізується шляхом формування та реалізації відповідної стратегії, розробки законодавчої бази, структури та інфраструктури ринку.

Ключові слова: інноваційний потенціал, національна економіка, система, якість, властивості, розвиток.

Kendiukhov O., Solokha D., Tanchyk O., Bieliakova $O$. The Theoretical Concepts of Innovative Potential Formation of National Economy

The main approaches to optimizing the competitive advantages of economic entities of Ukraine in the context of the implementation of the main provisions of the concept of sustainable development, taking into account the criterion of environmental efficiency, are considered.

Producers of environmental innovations should take into account the impact of environmental pressures and negative environmental impacts when assessing their chances of market success. There are radical environmental innovations that have no direct analogues. For this type of innovation in the analysis of demand and assessment of market prospects are advised to consider the following factors: a critical consumer of capital, critical suitability of the product, the critical minimum level of income, the critical level of risk, and the critical amount of free time consumer. The speed of overcoming these barriers affects the time required to introduce environmental innovations to the market, start generating demand, and increase sales.

For the formation of the domestic market of environmentally friendly products, it is necessary to create an adapted regulatory framework to stimulate producers and create a competitive environment. The mechanism for developing a strategy for the development of economic entities for the production of environmentally friendly goods is presented. The strategy is presented as a generalizing model of the actions necessary to achieve the goal. It is advisable to carry out strategic actions according to a certain algorithm, which is a logical sequence.

The procedure for certification of environmentally friendly products and the algorithm of this process based on the criterion of environmental efficiency of production systems are proposed. Certification allows you to get complete and reliable information about the production of environmentally friendly goods at all stages, gives consumers a guarantee of compliance with the norms and standards that confirm the environmental purity of products.

Objective comprehensive identification of the needs of the main consumer groups gradually forms the basis for the functioning of the market of environmentally friendly products. The diagnostic approach to its formation should be used in combination with the optimization approach, which is implemented through the formation and implementation of an appropriate strategy, the development of the legislative framework, the structure and infrastructure of the market.

Keywords: innovative potential of the national economy, system, quality, properties and development.

Кендюхов А. В., Солоха Д. В., Танчик Е. И., Белякова О. В. Теоретические концепции формирования инновационного потенциала национальной экономики

Рассмотрены основные подходы к оптимизации конкурентных преимуществ хозяйствующих субъектов Украины в контексте реализации основных положений концепции устойчивого развития с учетом критерия экологической эффективности.

Производителям экологических инноваций при оценке своих шансов на рыночный успех следует учитывать влияние факторов экологического давления и негативного воздействия окружающей среды. Существуют радикальные экологические инновации, не имеющие прямых аналогов. Для данного вида инноваций при анализе спроса и оценке рыночных перспектив рекомендуется учитывать следующие факторы: критический уровень потребительского капитала, критическую пригодность продукта, критический минимальный уровень дохода, критический уровень риска и критический объем свободного времени потребителя. Скорость преодоления этих барьеров влияет на время, необходимое для внедрения экологических инноваций на рынок, начало генерирования спроса и увеличение продаж.

Для формирования внутреннего рынка экологически чистой продукции необходимо создать адаптированную нормативную базу для стимулирования производителей и создания конкурентной среды. Представлен механизм разработки стратегии развития хозяйствующих субъектов по производству экологически чистых товаров. Стратегия представлена как обобщающая модель действий, необходимых для достижения цели. Стратегические воздействия целесообразно осуществлять по определенному алгоритму, представляющему собой логическую последовательность.

Предложена процедура сертификации экологически чистых товаров и алгоритм данного процесса на основе критерия экологической эффективности производственных систем. Сертификация позволяет получить полную и достоверную информацию о производстве экологически чистого товара на всех этапах, дает потребителям гарантию соблюдения норм и стандартов, подтверждающих экологическую чистоту продукции.

Объективное комплексное выявление потребностей основных групп потребителей постепенно формирует основу функционирования рынка экологически чистых товаров. Диагностический подход к его формированию должен использоваться в сочетании с оптимизационным подходом, который реализуется путем формирования и реализации соответствующей стратегии, разработки законодательной базы, структуры и инфраструктуры рынка.

Ключевые слова: инновационный потенциал, национальная экономика, система, качество, свойства, развитие.

Received by the editors: 15.10 .2020

and final form 29.12.2020 